\title{
Effect of Temperature and the Organic Phase Content on the Stripping of Mn(II) from a D2EPHA-KEROSENE Pseudo-Emulsion Using a Sulfuric Acid Aqueous Solution
}

\author{
Jaime Cristobal Rojas-Montes, Roberto Pérez-Garibay, Alejandro Uribe-Salas, Fabiola Nava-Alonso \\ Centro de Investigación y de Estudios Avanzados del IPN, Unidad Saltillo, Ramos Arizpe, México \\ Email: jaime.rojas@cinvestav.edu.mx
}

Received August 31, 2012; revised September 31, 2012; accepted October 10, 2012

\begin{abstract}
There are few studies oriented to analyze the interaction between the variables of the stripping process of actual leaching solutions. The aim of this work was to study the effect of temperature and the percent of organic phase in the stripping pseudo-emulsion (D2EPHA and kerosene) on the manganese stripping process. Other studied variables were the acid concentration $\left(\mathrm{H}_{2} \mathrm{SO}_{4}\right)$ in the aqueous phase, the percent of the organic phase in the pseudo-emulsion and the number of stripping stages. This information may be of interest to countries with radical temperature variations. It was discovered that in the range of $10^{\circ} \mathrm{C}$ to $50^{\circ} \mathrm{C}$, temperature improves the depletion of manganese from the D2EPHA. Additionally, the percent of the organic phase should be less than $90 \%$ by volume of the pseudo-emulsion to favour the manganese exchange. Moreover, the $\mathrm{H}_{2} \mathrm{SO}_{4}$ concentration in the aqueous phase should be less than $1 \mathrm{M}$ to avoid chemical instability of the organic phase.
\end{abstract}

Keywords: Manganese Solvent Extraction; Manganese Stripping; Manganese; Pyrolusite

\section{Introduction}

In the last few years, the world demand for manganese has increased due to steel production, primarily in China. The steelmaking industry consumes between $85 \%$ and $90 \%$ of the world's manganese production [1]. The electronic industry also consumes a large quantity of manganese (Mn) in the form of electrolytic- and chemicalgrade of manganese dioxide (EMD and CMD), for producing disposable and rechargeable batteries. Currently, the growing market of mobile communications has significantly increased the demand for batteries and consequently, for EMDs.

This growing demand for manganese makes low-grade ore processing an important alterative, with hydrometallurgy being the more profitable approach for this type of processing. One of the more recently developed processes for leaching low-grade manganese ore is reductive leaching in a stirred reactor, using $\mathrm{SO}_{2}$ gas [2], followed by solvent extraction, stripping and electrowinning.

The elimination of manganese impurities from leach liquors of other metals is the most common objective of solvent extraction studies of manganese, but there are few studies on solvent extraction and stripping to concentrate the manganese that is present in the leachate obtained by $\mathrm{SO}_{2}$ leaching of low-grade pyrolusite ores
[3-5]. Stripping manganese from solvent-extractant solutions is considered a simple process and maybe this is the explanation why there are few studies that analyse the interaction of the process variables to optimise the stripping process. The scope of this work was to study the effect of temperature, acid concentration $\left(\mathrm{H}_{2} \mathrm{SO}_{4}\right)$ in the aqueous phase, the percent of the organic phase in the pseudo-emulsion and the number of stripping stages on the extractant depletion. This paper may be of interest to operators of manganese stripping processes in plants where a dynamic range of operating temperatures exists.

\section{Background}

Solvent extraction is used to separate a component from a homogeneous solution by adding a second solvent that is immiscible in the first solvent and creates a solute distribution between the two phases. Extractant di-2 ethyl hexyl phosphoric acid (D2EHPA) dissolved in kerosene is the organic solution most frequently used in manganese extraction from an aqueous leach liquor [6]. Once the organic phase is manganese-enriched from the solvent extraction process, the next stage involves reversing the reaction to obtain a concentrated and acidified aqueous solution of manganese (stripping). The final concentrated manganese solution helps to increase the efficiency 
of the subsequent electrowinning process. Because stripping is the inverse process of solvent extraction, and according to Sato and Nakamura [6], extraction with D2EHPA is governed by a cationic mechanism, the stripping process may be described by Equation (1).

$$
\overline{M R_{n}}+n H^{+}=M^{n+}+\overline{n H R}
$$

where $M$ is the metal, $H R$ is the D2EHPA in the organic phase and $M R$ is the metal-organic complex in the organic solution. It should be noted that after stripping the manganese, the organic (solvent and extractant) and the aqueous phases are recycled to achieve both economic and environmental targets [7]. Several studies also report using a sulphuric acid solution to separate metals from the loaded organic phase [8-10]. Hossain et al. [11] performed manganese stripping in a batch process $\left(\mathrm{H}_{2} \mathrm{SO}_{4}\right.$, shaking speed of $300 \mathrm{rpm}$ and temperature of $25^{\circ} \mathrm{C}$, for a period of $2 \mathrm{~h}$ ), founding that $100 \%$ of Mn was stripped using a $0.4 \mathrm{M} \mathrm{H}_{2} \mathrm{SO}_{4}$ solution in a single stage process, and higher concentrations did not provide any additional benefit. Agatzini-Leonardou [12] studied the strippability of $\mathrm{Mn}$ (II) from Cyanex 272 into an aqueous solution containing $0.76 \mathrm{M}$ sulphuric acid, reaching manganese recoveries of $99 \%$ with diluted sulphuric acid and two stripping stages.

In other studies conducted by Saeed et al. [13] using liquid membrane extraction, the authors analysed the effect of the concentration of $\mathrm{H}_{2} \mathrm{SO}_{4}$ and $\mathrm{FeSO}_{4}$ in the stripping solution using concentrations from $0.25 \mathrm{M}$ to $0.75 \mathrm{M}$ and $1.58 \times 10^{-3} \mathrm{~mol} / \mathrm{dm}^{3}$ to $11.1 \times 10^{-3} \mathrm{~mol} / \mathrm{dm}^{3}$, respectively, maintaining a feed concentration of $1.82 \times$ $10^{-3} \mathrm{~mol} / \mathrm{dm}^{3}$ manganese ions in a $1 \mathrm{M} \mathrm{H}_{2} \mathrm{SO}_{4}$ solution. The authors conclude that by increasing the $\mathrm{H}_{2} \mathrm{SO}_{4}$ concentration from $0.25 \mathrm{M}$ to $0.50 \mathrm{M}$, the extraction of $\mathrm{Mn}(\mathrm{II})$ ions also increases. Beyond this concentration of $\mathrm{H}_{2} \mathrm{SO}_{4}$, the extraction of $\mathrm{Mn}(\mathrm{II})$ ions decreases. Additionally, as the concentration of ferrous ions in the stripping phase increases gradually, the dissociation of the $\left(\mathrm{C}_{2} \mathrm{H}_{4} \mathrm{OH}\right)_{3} \mathrm{NHMnO}_{4}$ complex by a redox reaction at the membrane interface is enhanced, and $\mathrm{Mn}(\mathrm{II})$ ions are released into the stripping phase.

Cheng [14] conducted another study to improve the nickel, cobalt and manganese stripping kinetics, adding TBP (tri-n-butyl-phosphate) in a V10 (tertiary carboxylic acid)/L63 (an $\alpha$-hydroxyoxime) system. Stripping tests were conducted using the loaded Versatic 10/LIX63/TBP system containing $2.25 \mathrm{~g} / \mathrm{L} \mathrm{Ni}, 0.112 \mathrm{~g} / \mathrm{L} \mathrm{Co}$ and 0.033 $\mathrm{g} / \mathrm{L} \mathrm{Mn}$. Additionally, a synthetic spent-nickel electrolyte containing $6 \mathrm{~g} / \mathrm{L} \mathrm{Ni}$ and $7 \mathrm{~g} / \mathrm{L}$ sulphuric acid was added to the system at an organic:aqueous $(\mathrm{O}: \mathrm{A})$ ratio of $1: 1$ at $40^{\circ} \mathrm{C}$ to mimic an operation with a strip solution containing $60 \mathrm{~g} / \mathrm{L}$ nickel and $70 \mathrm{~g} / \mathrm{L}$ sulphuric acid at an O:A ratio of 10:1. The authors observed rapid stripping kinetics for the three metals. After 2 min of mixing, the strip- ping efficiencies of nickel, cobalt and manganese were $92 \%, 98 \%$ and $99 \%$, respectively.

\section{Experimental Procedure}

\subsection{Leaching and Solvent Extraction}

Manganese dissolution was conducted by reductive leaching of the pyrolusite mineral $\left(\mathrm{d}_{10}=38 \mu \mathrm{m}\right)$ using $\mathrm{SO}_{2}$ gas. The elemental analysis of the ore was conducted using X-ray fluorescence (\%, w/w): Mn (18.80), Fe (12.81), Si (23.83), Al (1.18), Ba (1.11), Ca (0.59) and O (42). Based on this analysis and on the stoichiometry of the oxidised species, a mineralogical composition was estimated $(\%$, w/w): $\mathrm{MnO}_{2}$ (28.78), $\mathrm{Fe}_{2} \mathrm{O}_{3}$ (17.72), $\mathrm{SiO}_{2}$ (49.33), $\mathrm{Al}_{2} \mathrm{O}_{3}$ (2.15), $\mathrm{BaO}$ (1.19) and $\mathrm{CaO}$ (0.79). Notably, these results are in qualitative agreement with the results obtained using X-ray diffraction. The leaching process was performed in a $2 \mathrm{~L}$ reactor operated in batch mode. The reactor was properly equipped to measure and control the temperature, $\mathrm{pH}$, mixing rate and $\mathrm{SO}_{2}$ gas flow fed to the reactor. The leaching process was performed at $60^{\circ} \mathrm{C}$ and a stir speed of $800 \mathrm{rpm}$ for 120 minutes in $1600 \mathrm{~mL}$ of pulp and $0.096 \mathrm{~mL} / \mathrm{s}$ of $\mathrm{SO}_{2}$ gas. The process yielded $90 \% \mathrm{Mn}$ and $0.17 \% \mathrm{Fe}$, which was present as a solute in the leach liquor. The insufficient Fe dissolution likely occurred because most of the Fe was occluded into quartz particles. Thus, the manganese concentration in the leach liquor was close to $0.085 \mathrm{M}$. After the leaching, the liquor was separated from the solids by filtration.

Considering that the selectivity of the extractants for the ions of interest is $\mathrm{Fe}(\mathrm{II}), \mathrm{Fe}(\mathrm{III})>\mathrm{Mn}(\mathrm{II})$, it was necessary to eliminate the Fe impurities from the leach solution prior to the extraction stage. To precipitate the $\mathrm{Fe}$ impurities, the $\mathrm{pH}$ was increased to 7.2 with $5 \mathrm{M} \mathrm{NH}_{4} \mathrm{OH}$, carefully avoiding the co-precipitation of $\mathrm{Mn}(\mathrm{II})$, which occurs when the $\mathrm{pH}$ is above 8.2. Initially, the leaching solution contained $5520 \mathrm{ppm}$ of $\mathrm{Mn}$ and $85.04 \mathrm{ppm}$ of Fe. After the precipitation of $\mathrm{Fe}(\mathrm{OH})_{2}$, the iron content dropped to approximately $0.03 \mathrm{ppm}$, and only a relatively small fraction $(7.34 \%)$ of $\mathrm{Mn}$ (II) precipitated with the iron. Table 1 shows the chemical analysis of the purified leached solution, which includes low contents of other metals.

Table 1. Chemical analysis of the leach liquor before and after the precipitation of $\mathrm{Fe}(\mathrm{OH})_{2}$.

\begin{tabular}{ccc}
\hline Element & Before purification $(\mathrm{ppm})$ & After purification $(\mathrm{ppm})$ \\
\hline $\mathrm{Mn}$ & 5520 & 5115 \\
$\mathrm{Fe}$ & 85.04 & 0.020 \\
$\mathrm{Zn}$ & 2.79 & 0.166 \\
$\mathrm{Cd}$ & $<0.003$ & $<0.003$ \\
$\mathrm{Cu}$ & 1.36 & 0.08 \\
$\mathrm{Mg}$ & 21.65 & 21.08 \\
$\mathrm{Co}$ & 0.246 & 0.1 \\
$\mathrm{Ni}$ & 1.04 & 0.529 \\
\hline
\end{tabular}


For the solvent extraction, the organic solution was prepared by diluting the extractant in kerosene with a D2EHPA:kerosene proportion of $1: 9$ by volume. The organic and aqueous (leaching purified liquor) solutions were mixed in a $2 \mathrm{~L}$ reactor for 5 minutes, keeping a ratio $\mathrm{O}: \mathrm{A}$ of 2. It was used five minutes to assure a good metal exchange, even when it has been reported that a mixing time of one minute is sufficient for this type of solvent extractions [15]. After each extraction stage, the mixture was left to stand for 15 minutes, permitting the complete separation of the phases, to adjust the $\mathrm{pH}$ of the aqueous solution. Notably, this procedure was conducted five times (i.e., five extraction stages). Before and after each extraction stage, the $\mathrm{pH}$ of the aqueous phase was measured and eventually adjusted between 8 and 8.5 with a 1 $\mathrm{M} \mathrm{NH}_{4} \mathrm{OH}$ solution. After the five extraction stages, the organic phase passed to the stripping process, and a sample of the aqueous solution was withdrawn for chemical analysis in order to estimate the manganese recovered by the solvent extraction procedure.

\subsection{Stripping}

The stripping tests were performed in a $125 \mathrm{~mL}$ separation funnel, varying the organic: aqueous phase ratio in each experiment. Additionally, different concentrations of $\mathrm{H}_{2} \mathrm{SO}_{4}$ in the aqueous phase were used during the stripping tests. Similar to the solvent extraction tests, the

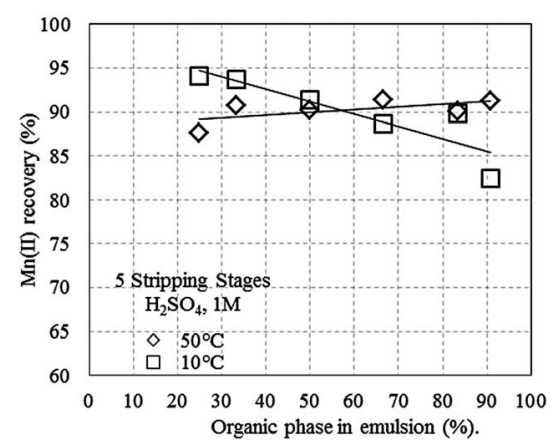

(a)

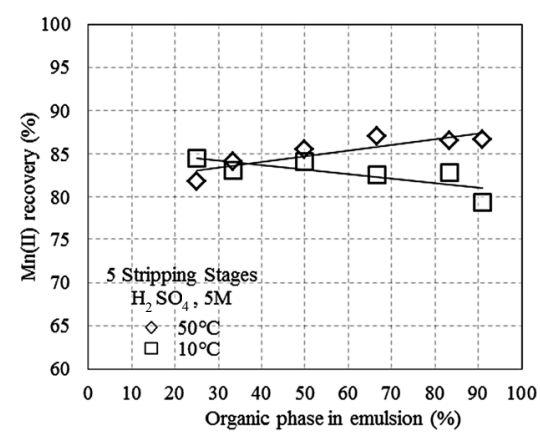

(c) pseudo-emulsions were mixed vigorously for 1 minute and left to stand for 20 minutes, following the complete separation of the phases. After each stripping test, a sample of the aqueous solution was withdrawn for chemical analysis (atomic absorption spectroscopy) to estimate the recovery of manganese. The experimental stripping conditions are listed in Table 2.

\section{Results and Discussion}

Figures 1(a)-(c) shows the manganese recovery as a function of the percent of the organic phase that is present in the pseudo-emulsion with the aqueous solution, at different $\mathrm{H}_{2} \mathrm{SO}_{4}$ concentrations $(1,3$, and $5 \mathrm{M})$. The tests were conducted with five stripping stages at $10^{\circ} \mathrm{C}$ and $50^{\circ} \mathrm{C}$, and recoveries between $82 \%$ and $92 \%$ were obtained. Additionally, at $50^{\circ} \mathrm{C}$ manganese recovery increased with the percentage of the organic phase, while

Table 2. Experimental conditions of the stripping tests.

\begin{tabular}{cc}
\hline Variable & Operation conditions \\
\hline Concentration of $\mathrm{H}_{2} \mathrm{SO}_{4}(\mathrm{M})$ & 1,3 and 5 \\
\hline $\begin{array}{c}\text { Organic in the organic-aqueous mixture } \\
(\% \text { by volume })\end{array}$ & $\begin{array}{c}25.0 ; 33.3 ; 50.0 ; 66.6 ; 83.3 ; \\
\text { Number of stripping stages } \\
\text { Temperature }\left({ }^{\circ} \mathrm{C}\right)\end{array}$ \\
\hline
\end{tabular}

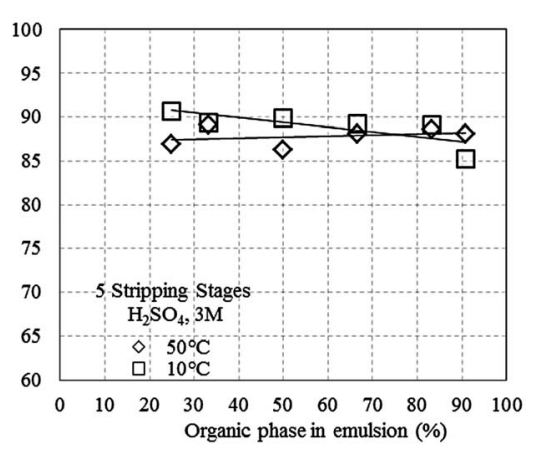

(b)

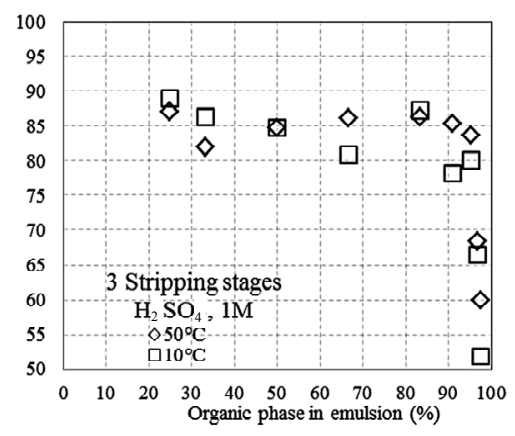

(d)

Figure 1. Recovery of $\mathrm{Mn}$ (II) as a function of the percent of the organic phase in the pseudo-emulsion and the temperature, when five stripping stages are performed. (a) Aqueous solution with $\mathrm{H}_{2} \mathrm{SO}_{4} 1 \mathrm{M}$; (b) Aqueous solution with $\mathrm{H}_{2} \mathrm{SO}_{4} 3 \mathrm{M}$; (c) Aqueous solution with $\mathrm{H}_{2} \mathrm{SO}_{4} 5 \mathrm{M}$; (d) Three stripping stages and aqueous solution with $\mathrm{H}_{2} \mathrm{SO}_{4} 1 \mathrm{M}$. 
at $10^{\circ} \mathrm{C}$ the recovery decreased when the organics in the pseudo-emulsion increased. This result is likely due to the organic phase being less viscous at $50^{\circ} \mathrm{C}$, which improves the pseudo-emulsion droplet formation and increases the contact surface area, thus increasing the migration of manganese from the organic phase to the aqueous phase. In general, after the stripping, the aqueous solutions reach $40 \mathrm{~g} / \mathrm{m}^{3}$ of $\mathrm{Mn}(\mathrm{II})$.

Comparing the results in Figures 1(a) and (b), a little advantage of using solutions acidified at $1 \mathrm{M}$ is noticed. This result is possibly due to the low viscosity of the system under these experimental conditions, which enhances contact between the organic and the aqueous phases. It is also possible that under highly acidic conditions, the organic phase becomes chemically instable. This is suggested by the colour change that occurs when the $\mathrm{H}_{2} \mathrm{SO}_{4}$ concentration is greater than $1 \mathrm{M}$. Table 3 shows the recovery of the impurities in a typical test of stripping $(50 \%$ of organic phase, aqueous solution $1 \mathrm{M}$ $\mathrm{H}_{2} \mathrm{SO}_{4}, 25^{\circ} \mathrm{C}$ and 3 stripping stages).

Figure 1(d) shows the results of the tests conducted with 3 stripping stages and a $\mathrm{H}_{2} \mathrm{SO}_{4} 1 \mathrm{M}$ solution. Below an organic phase percentage of $90 \%$, the results were similar to those obtained in tests using 5 stripping stages. Above this percentage, several changes were observed. The aim of these tests was to determine the maximum content of the organic phase needed to maintain the efficiency of the stripping process. At both $10^{\circ} \mathrm{C}$ and $50^{\circ} \mathrm{C}$, above $90 \%$ of the organic phase in the pseudo-emulsion, the manganese recovery decreases drastically, indicating that a high percent of organic phase in the pseudo-emulsion affects the interaction between both phases, enhancing the mass transfer and the manganese recovery. Comparing Figures 1(a) and (d), the number of stripping stages does not significantly affect the recovery, suggesting that 3 stages are sufficient for good recovery.

Additionally, the interval of the studied temperatures was selected because en some places the atmospheric temperature can oscillate between $-10^{\circ} \mathrm{C}$ and $45^{\circ} \mathrm{C}$, and consequently, the temperature of the fluids in the extraction processes may be close to the studied range. Also, it is observed that it is possible to predict the manganese recovery as a function of the percentage of the organic phase and the temperature.

Table 3. Recovery of impurities in the stripping stage. Organic phase in pseudo-emulsion $50 \%$, aqueous phase $1 \mathrm{M}$ $\mathrm{H}_{2} \mathrm{SO}_{4}, 25^{\circ} \mathrm{C}$ and 3 stripping stages.

\begin{tabular}{cc}
\hline Impurity & Recovery in stripping (\%) \\
\hline $\mathrm{Fe}$ & 0 \\
$\mathrm{Zn}$ & 100 \\
$\mathrm{Cd}$ & 0 \\
$\mathrm{Cu}$ & 0 \\
$\mathrm{Mg}$ & 62.89 \\
$\mathrm{Co}$ & 0 \\
$\mathrm{Ni}$ & 93.09 \\
\hline
\end{tabular}

\section{Conclusions}

Manganese complexed with D2EHPA dissolved in kerosene was extracted using an aqueous solution of sulphuric acid. The process variables that were evaluated included the operating temperature $\left(10^{\circ} \mathrm{C}\right.$ and $\left.50^{\circ} \mathrm{C}\right)$, the acid concentration $(1,3$ and $5 \mathrm{M})$ in the aqueous phase and the number of extraction stages ( 3 and 5).

It was discovered that temperature (between $10^{\circ} \mathrm{C}$ and $50^{\circ} \mathrm{C}$ ) improves the depletion of manganese from the D2EPHA.

The percentage of the organic phase should be less than $90 \%$ of the pseudo-emulsion to favour manganese exchange.

The concentration of $\mathrm{H}_{2} \mathrm{SO}_{4}$ in the aqueous phase should be less than $1 \mathrm{M}$ to avoid chemical instability of the organic phase.

Considering the environmental and economic impact, it is suggested to work under the following operation conditions: ambient temperatures, 3 stripping stages, pseudo-emulsions that contain less than $90 \%$ of organic phase and aqueous solutions with a maximal $\mathrm{H}_{2} \mathrm{SO}_{4}$ concentration (1 M).

\section{Acknowledgements}

The authors are grateful to CONACYT (Mexico) and to Huajicari S.A. de C.V. for the providing the funding for this research.

\section{REFERENCES}

[1] L. A. Corathers, "US Geological Survey (USGS) Minerals Yearbook: Manganese-2005,” 2007. http://minerals.usgs.gov

[2] W. Zhang and C. Y. Cheng, "Manganese Metallurgy Review: Part I: Leaching of Ores/Secondary Materials and Recovery of Electrolytic/Chemical Manganese Dioxide," Hydrometallurgy, Vol. 89, No. 3-4, 2007, pp. 137-159. doi:10.1016/j.hydromet.2007.08.010

[3] N. Mulaudzi and T. Mahlangu, "Oxidative Precipitation of $\mathrm{Mn}(\mathrm{II})$ from Cobalt Leach Solutions Using Dilute $\mathrm{SO}_{2} /$ Air Gas Mixture," The Journal of Southern African Institute of Mining and Metallurgy, Vol. 109, 2009, pp. 375381.

[4] J. Van Rooyen, S. Archer and M. Fox, "Manganese Removal from Cobalt Solutions with Dilute Sulphur Dioxide Gas Mixtures," The Fourth Southern African Conference on Base Metals, The Southern Africa Institute of Mining and Metallurgy, 2009, pp. 365-376.

[5] V. Menard and G. Demopuolos, "Gas Transfer Kinetics and Redox Potential Considerations in Oxidative Precipitation of Manganese from an Industrial Zinc Sulphate Soltion with $\mathrm{SO}_{2} / \mathrm{O}_{2}$," Hydrometallurgy, Vol. 89, No. 3-4, 2007, pp. 357-368. doi:10.1016/j.hydromet.2007.03.014

[6] T. Sato and T. Nakamura, "Solvent Extraction of Divalent Metals from Sulfuric Acid Solutions by Dialkylphos- 
phoric Acid," Journal of the Mining and Metallurgical Institute Japan, Vol. 101, No. 1167, 1985, pp. 309-312.

[7] J. Rydberg, M. Cox and C. Musikas, "Solvent Extraction Principles and Practice,” CRC Rress, 2004, p. 480. doi:10.1201/9780203021460

[8] D. Mohapatra, K. Hong-In, C. W. Nam and K. H. Park, "Liquid-Liquid Extraction of Aluminium(III) from Mixed Sulphate Solutions Using Sodium Salts of Cyanex 272 and D2EHPA," Separation and Purification Technology, Vol. 56, No. 3, 2007, pp. 311-318. doi:10.1016/j.seppur.2007.02.017

[9] X. P. Huo, W. Qin, X. W. Sun and Y. Y. Dai, "Recovery of Chromium (III) by Solvent Extraction with D2EHPA," Journal of Chemical Engineering of Chinese Universities, Vol. 21, No. 5, 2007, pp. 849-852.

[10] Z. G. Arroyo, M. Stambouli, D. Pareau, A. Buch, G. Durand and M. A. Rodriguez, "Thiosubstituted Organophosphorus Acids as Selective Extractants for Ag(I) from Acidic Thiourea Solutions," Solvent Extraction and Ion Exchange, Vol. 26, No. 2, 2008, pp. 128-144. doi:10.1080/07366290801904855

[11] M. R. Hossain, S. Nash, G. Rose and S. Alam, "Cobalt Loaded D2EHPA for Selective Separation of Manganese from Cobalt Electrolyte Solution," Hydrometallurgy, Vol. 107, No. 3-4, 2011, pp. 137-140. doi:10.1016/j.hydromet.2011.02.011

[12] S. Agatzini-Leonardou, P. E. Tsakiridis, P. Oustadakis, T. Karidakis and A. Katsiapi, "Hydrometallurgical Process for the Separation and Recovery of Nickel from Sulphate Heap Leach Liquor of Nickeliferrous Laterite Ores," Minerals Engineering, Vol. 22, No. 14, 2009, pp. 1181-1192. doi:10.1016/j.mineng.2009.06.006

[13] S. ur Rehman, G. Akhtar, M. A. Chaudry, N. B. Najeebullah and N. Ali, "Mn (VII) Ions Transport by Triethanolamine Cyclohexanone Based Supported Liquid Membrane and Recovery of Mn (II) Ions from Discharged Zinc Carbon Dry Battery Cell," Journal of Membrane Science, Vol. 366, No. 1-2, 2011, pp. 125-131. doi:10.1016/j.memsci.2010.09.049

[14] C. Y. Cheng, G. Boddy, W. Zhang, M. Godfrey, D. J. Robinson, Y. Pranolo, Z. Zhu and W. Wang, "Recovery of Nickel and Cobalt from Laterite Leach Solutions Using Direct Solvent Extraction: Part 1-Selection of a Synergistic SX System," Hydrometallurgy, Vol. 104, No. 2, 2010, pp. 45-52. doi:10.1016/j.hydromet.2010.04.009

[15] R. K. Biswas, M. A. Habib and M. G. K. Mondal, "Kinetics and Mechanism of Stripping of Mn(II)-D2EHPA Complex by Sulfuric Acid Solution," Hydrometallurgy, Vol. 80, No. 3, 2005, pp. 186-195. doi:10.1016/j.hydromet.2005.06.013 